
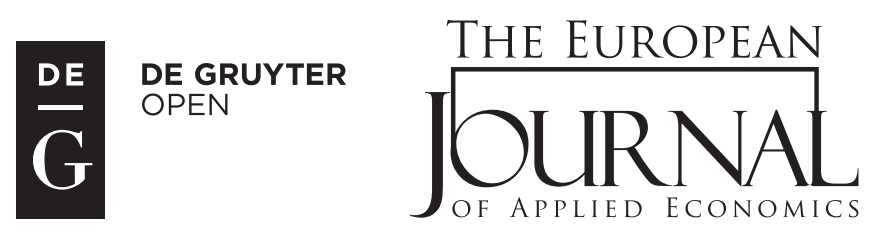

EJAE 2016, 13(1): 13-23

ISSN 2406-2588

UDK: $330.341 .1(4-773)$

005.591.3:621.39(4-773)

004.738 .5

657.471.1:624(612)

DOI: $10.5937 /$ ejae13-10126

Original paper/Originalni naučni rad

\title{
THE MODEL FOR SUCCESSFUL DEVELOPMENT OF NGA INFRASTRUCTURE IN THE BALKANS
}

\author{
Matej Požarnik, Lea Robič Mohar*, Tea Taras \\ ProFUTURUS d.o.o., \\ 11 Črtomirova St., Maribor, Slovenia
}

\begin{abstract}
:
Unavailability of fast broadband internet access, primarily due to the lack of commercial interest of telecommunication operators, is the key reason for economic underdevelopment in rural areas in the Balkans. The process of developing broadband access in rural areas is multifaceted, complex and time-consuming. This paper analyses the current state of availability of broadband access in the Balkan countries, and investigates the algorithm with specific project phases and benefits of stakeholders at the national and local level. The purpose of the paper is to develop the model that rationalizes the implementation process of the broadband internet access projects, and to define the method of selecting an investment model for construction of broadband infrastructure. The results show that the Balkan countries have to start with preparatory activities and studies needed for successful implementation of the given model. This research contributes to stopping demographic and socio-economic degradation in less-developed areas, at the same time encouraging their development.
\end{abstract}

\section{Key words:}

cohesion policy, broadband infrastructure, financing model, EUBB model.

\section{INTRODUCTION}

The crucial reason for slow progression of the Balkan rural areas is unavailability of modern information and communication technology (ICT) solutions. Undoubtedly, the implementation of broadband access development (BBAD) project is complex and time-consuming. The decisionmakers are therefore confronted with the issue of accelerating the project preparation procedures and making them less demanding and more effective. The Balkan countries must be e-ready in terms of infrastructure development. As defined by
Osmanbegović and Rožajac (2013), it would enable the use of ICT for enhancement of demographic and socio-economic state, and consequently the quality of life. Cooperation of national, regional and local institutions is therefore of vital importance in the process. As outlined by Kramer et al. (2006), this type of projects is co-financed by the European Union's (EU) financial instruments due to the benefits of broadband access. Tolušić et al. (2013) proposed that high-quality and efficient project management, as well as high-quality project documentation are the key elements for successful project funding by the EU. 
This paper analyses state-of-the-art broadband access. On the other hand, it also introduces the implementation procedure for BBAD projects beyond the state-of-the-art. A SWOT analysis for the project of developing broadband access is demonstrated in the results, providing explanation for the extended duration of the BBAD project in rural areas. The paper identifies the challenges stakeholders encountered during the project implementation and proposes guidelines for process optimization. Moreover, it defines a model for selection of an investment model for BBAD projects, the aim of it being facilitation and acceleration of the BBAD project preparation process. Adequately defined legislative and strategic foundations and database, as well as properly prepared project documentation and application of the optimal investment model are the preconditions for successful BBAD implementation. Roetter (2013) outlined that the abovementioned projects improve the quality of life in less-developed or rural areas. In accordance with non-profitability of solely private investments in broadband infrastructure, the EUBB model represents a sustainable model for BBAD projects, using the European cohesion policy as a stimulus for projects in rural Balkan areas.

\section{THESIS}

The investment costs of developing the next generation access (NGA) broadband infrastructure outside the urban centers in the Balkans are rather high. Operators' revenue in defined are as is insufficient to make the investments pay off over a period of 20 years. Therefore, operators have no commercial interest to develop NGA broadband infrastructure in the given areas. Despite the above mentioned situation, the European Broadband (EUBB) model enables efficient development of NGA broadband infrastructure in the areas without commercial interests of operators. Efficient development is a crucial factor in achieving the objectives of the European cohesion policy in the
Balkan countries as future members of the EU. By utilizing the EU funds, the EUBB model constitutionalizes the process of $\mathrm{BBAD}$, incorporating the best practices in prospective projects.

\section{METHODOLOGY}

The survey collected all relevant documents, while the descriptive method provided the strategic-legislative basis of the European cohesion policy. The inductive method provided general conclusions about the current state of the economy and broadband internet access in Slovenia, Croatia and the Balkan countries. Over the last seven years of preparing concrete ICT projects in Slovenia and Croatia, explicated phases and certain challenges of BBAD projects implementation have been investigated. After a thorough analysis, a model for project preparation and implementation in the Balkans was proposed.

\section{STRATEGIC-LEGISLATIVE BASIS}

Europe 2020 strategy is the master strategy of the European Union whose main goal is to transform the EU into a smart, sustainable and inclusive economy that will boost employment possibilities, productivity and social cohesion (Lundvall \& Lorenz, 2012). The priority Smart growth includes investments into education and research, and research and innovation. It is supported by the following leading initiatives (European Commission, 2010b):

- Digital Agenda for Europe (DAE),

- Innovation Union,

- Youth on the move.

Each member state is recommended to include the strategic goals into its national goals, depending on the national priorities (Grgurić, 2010). Europe 2020 strategy aims to capitalize the effects of innovation and ICT growth through one of its flagship initiatives and DAE (Veugelers, 2012). The aim of DAE is to maximize the social and economic potential of ICT, especially the Internet, as the most important 
medium of social and economic activity (Marcus \& Elixmann, 2012), with the following goals:

1. Presence of full broadband coverage of minimum speed of $\geq 30 \mathrm{Mbit} / \mathrm{s}$,

2. Subscription by at least $50 \%$ of households with a broadband minimum speed of $\geq 100 \mathrm{Mbit} / \mathrm{s}$ (European Commission, 2010a).

In order to achieve the above-specified goals, the existing network infrastructure has to be extended by a mix of technologies (Gruber et al., 2014). In order not to deteriorate competitiveness by allocating state aid for the construction of broadband infrastructure, certain rules were made regarding the financing of its construction (Briglauer, 2013). "EU Guidelines for the application of State aid rules in relation to rapid deployment of broadband networks" defines the policy of neutrality principles: obligation to openness and neutrality of the network, and the obligation to technological neutrality of projects. The results of the particular study encourage regulated open access to the broad band infrastructure (Kongaut \& Bohlin, 2014)

\section{ECONOMIC INDICATORS AND AVAILABILITY OF BROADBAND ACCESS}

Densely populated urban areas show satisfactory coverage of NGA (Briglauer, 2015), while the majority of population cannot access the fast-speed broadband (Ministry of Regional Development and EU funds, 2014). Preceding data involves areas where demographic and socio-economic indicators as well as the quality of life lay behind the rest of the country (National Statistics Bureau, 2015) and the EU. Table 1 and Table 2 show the selected economic and ICT indicators, related to the development of broadband infrastructure in the selected areas.

\begin{tabular}{ccc}
\hline Area & GDP (PPS) per capita & Unemployment level \\
\hline Average EU28 $(\mathrm{EU}=100)$ & 100 & $10.2 \%$ \\
\hline Slovenia & 83 & $9.7 \%$ \\
\hline Croatia & 59 & $17.3 \%$ \\
\hline Serbia & 37 & $16.7 \%$ \\
\hline Montenegro & 41 & $16.5 \%$ \\
\hline Macedonia & 37 & $28.0 \%$ \\
\hline Bosnia and Herzegovina $(\mathrm{B} \& \mathrm{H})$ & 29 & $27.5 \%$ \\
\hline
\end{tabular}

Table 1. Values of selected indicators of the state of economy (2014 or the last available year) Source: Eurostat 2015, Statistical Bureau of Serbia, Montenegro, Macedonia and B\&H

\begin{tabular}{cccc}
\hline Area & $\begin{array}{c}\text { Households that own a } \\
\text { personal computer }\end{array}$ & $\begin{array}{c}\text { Households with internet } \\
\text { access }\end{array}$ & $\begin{array}{c}\text { Subscription to stationary } \\
\text { broadband access }\end{array}$ \\
\hline Average EU28 & $82.0 \%$ & $83.0 \%$ & $69.9 \%$ \\
\hline Slovenia & $76.4 \%$ & $75.6 \%$ & $25.0 \%$ \\
\hline Croatia & $66.3 \%$ & $64.6 \%$ & $21.5 \%$ \\
\hline Serbia & $62.7 \%$ & $48.0 \%$ & $14.2 \%$ \\
\hline Montenegro & $53.8 \%$ & $55.0 \%$ & $12.8 \%$ \\
\hline Macedonia & $68.3 \%$ & $61.9 \%$ & $15.1 \%$ \\
\hline
\end{tabular}

Table 2. Values of selected indicators of ICT readiness (2013 or the last available year)

Source: Eurostat 2015, The Global Information Technology Report 2015, ICTs for Inclusive Growth, 2015 


\section{BENEFITS OF BROADBAND INFRASTRUCTURE}

According to the analysis of the World Bank, investing 1,000,000 Kuna into broadband access will provide 5 to 15 new work places; while a 10\% increase of investments into broadband access will result in increasing the gross national product from $1.21 \%$ in developed countries to $1.38 \%$ in underdeveloped countries (Qiang et al., 2009). The impact of investments in broadband access is shown in Figure 1.

Affirmative influence of the availability of broadband access at the local level is reflected as defined:

- Digital standard of living is becoming the same as in the rest of the state; this results in preventing reduction of population, or even emigration,

- Creating potential for development of independent economic activities or various aspects of distance work and work from home, which will contribute to retaining and attracting younger and working population (Van der Wee et al., 2015),

- Reducing the costs of health services, especially for an ageing population due to the potential introduction of e-health services (Currie et al., 2015).
- Increase the availability of educational services, especially in the context of lifelong learning for the elderly population, or part of the population with unsatisfactory highest achieved level of education, by means of e-education and distance learning (Rampersad \& Troshani, 2013),

- Increase the share of the population with the highest level of attained education by $4.5 \%$ on average; all this stems from longterm availability of advanced broadband services, related to education (Ministry of Maritime Affairs, Transport and Infrastructure, 2014).

Long-term benefits (Briglauer \& Gugler, 2013), brought by broadband access are seen through increase of the analysed key indicators:

- Gross domestic product (GDP) growth: estimates of the GDP growth rate vary from $0.47 \%$ to $1.38 \%$ over a period of several years in which there was a significant increase of broadband access users,

- Creating new jobs, related to the construction of broadband infrastructure: estimates for Croatia foresee 40,000 new work places in the period of achieving DAE objectives by the end of 2020 (Ministry of Maritime Affairs, Transport and Infrastructure, 2014).

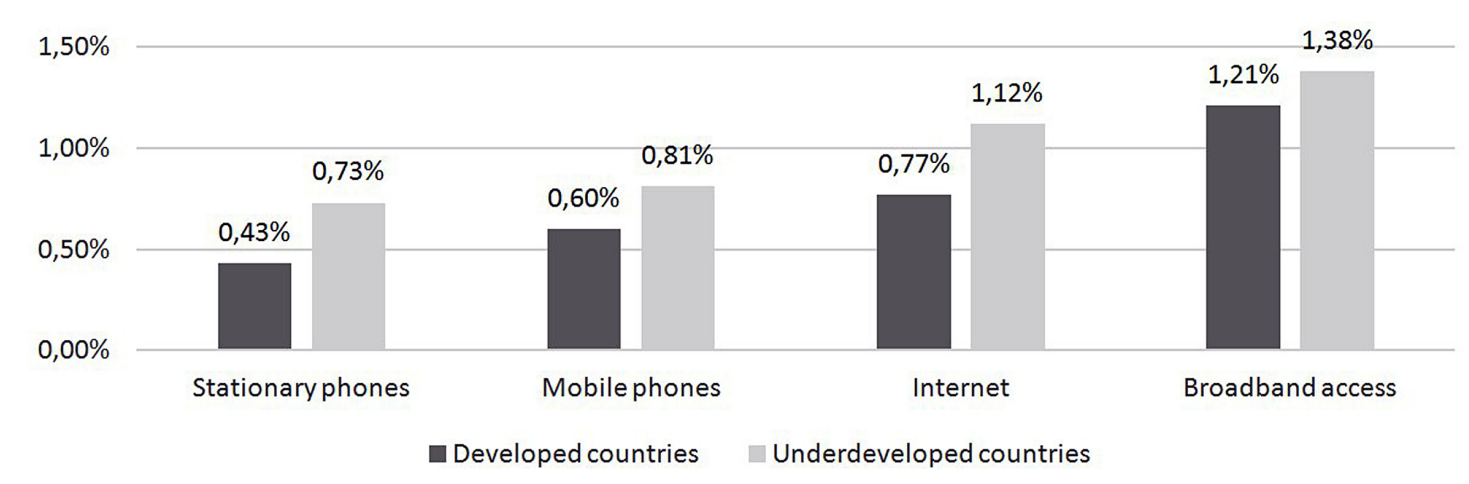

Figure 1. The impact of $10 \%$ increase of investments on GDP increase 


\section{RESULTS}

\section{THE NEED FOR EU CO-FINANCING}

Profitability analysis was produced upon exploring the operator's commercial interest for development of the NGA broadband infrastructure in less populated rural Balkan areas. The following assumptions were considered:

1. Area: less populated, rural (average distance between houses is $6.5 \mathrm{~km}$ ).

2. Number of ports to be built: 15,000 .

3. Average price per portFiber to the cabinet/ Fiber to the house (FTTC/FTTH): 1,060 EUR.

4. Expected network utilization: $54 \%$.

5. Active equipment amortization: $10 \%$.

6. Passive network segment amortization: $5 \%$.

7. Economic period: 20 years.

The profitability analysis relates to $87 \%$ of households in the Balkan countries. The results of the analysis are shown in Table 3.

\begin{tabular}{lc}
\hline \multicolumn{1}{c}{ Indicator } & Value \\
\hline Investment costs & $15.900 .000 \mathrm{EUR}$ \\
\hline Financial Net Present Value & $-8.900 \mathrm{EUR}$ \\
\hline $\begin{array}{l}\text { Financial Rate of Return of the } \\
\text { Investment }\end{array}$ & $-3.35 \%$ \\
\hline Relative net present value & $-0,5633$ \\
\hline The payback period & $<20$ years \\
\hline $\begin{array}{l}\text { Financial Rate of Return on } \\
\text { National Capital }\end{array}$ & $2.25 \%$ \\
\hline
\end{tabular}

Table 3. Profitability analysis

Financial Net Present Value at the end of the referring period shows financial non-profitability of the project, and thus the need for co-financing with the EU funds. Moreover, because of the high investments and low net revenues to cover those investments during the economic period, all dynamic financial indicators are negative, thus showing financial non-profitability of the project. As Katz (2008) concludes, the state-of-the-art BBAD project investing models, considering the absence of positive returns, "could be at serious risk". On the other hand, financial internal rate of return after EU co-financing shows cost-effectiveness of the national equity. Values below the discount rate suggest that EU support is not over-proportionate. It can be concluded that EU funds are essential.

\section{SWOT ANALYSIS OF THE PROJECT}

SWOT analysis of the project for development of broadband internet access defines the internal strengths and weaknesses of the project, as well as positive and negative external factors; i.e. opportunities and risks in terms of external project threats. The SWOT analysis of BBAD projects is shown in Figure 2.

Internal strength of the BBAD project is a know-how of contractors, performers of preparatory project phases and their high professional capacities. In the Balkan area, there are segments of infrastructure that can be used in BBAD projects, which would result in a decrease of investment costs. Projects have very positive effects on demographic and socio-economic situation in the implemented area. Project weaknesses mostly reflect in their complexity and length. However, because of the EU's co-financing approach to such projects through EU funds $(85 \%+15 \%$ national share), projects have great support of the public authorities, which presents a huge opportunity. Due to the financial crisis and lack of information technology (IT) awareness among older residents, there is a significant digital gap between the urban and rural areas in which the projects are planned. Considering the risk of too low revenue, low utilization of the new network is recognized as the biggest threat to the overall project success.

\section{EUBB MODEL FOR EFFECTIVE DEVELOPMENT OF RURAL AREAS}

According to Zhen-Wei Qiang (2010), six key considerations for public interventions should 


\section{STRENGTHS}

- High professional capacities and experience of stakeholders.

- Existing infrastructure of operators.

- Positive effects of broadband access.

\section{WEAKNESSES}

- Project complexity.

- Long duration of the project.

- Financial non-profitability.

\section{OPPORTUNITIES}

- Public administration support.

- Possibility of co-financing through EU funds.

- Increasing demand for broadband internet access.

- Interest of the EU and home countries to expand broadband access.

- Further development of e-government services.

\section{THREATS}

- Inaccessibility and poor data updates.

- Restricting funding possibilities.

- Lack of information awareness and computer literacy in rural areas.

- Financial crisis.

- Low rate of households owning a computer in rural areas.

\section{Figure 2. SWOT analysis of broadband access projects development}

be taken into account in BBAD project financing structure projects, co-financed by the EU. Figure models. Considering that and the current condi- 3 shows a graphic demonstration of project phases tions in the Balkans, the EUBB model is a powerful with the implementation of the EUBB model. model for implementation of broadband infra- Below are given the specific project phases.

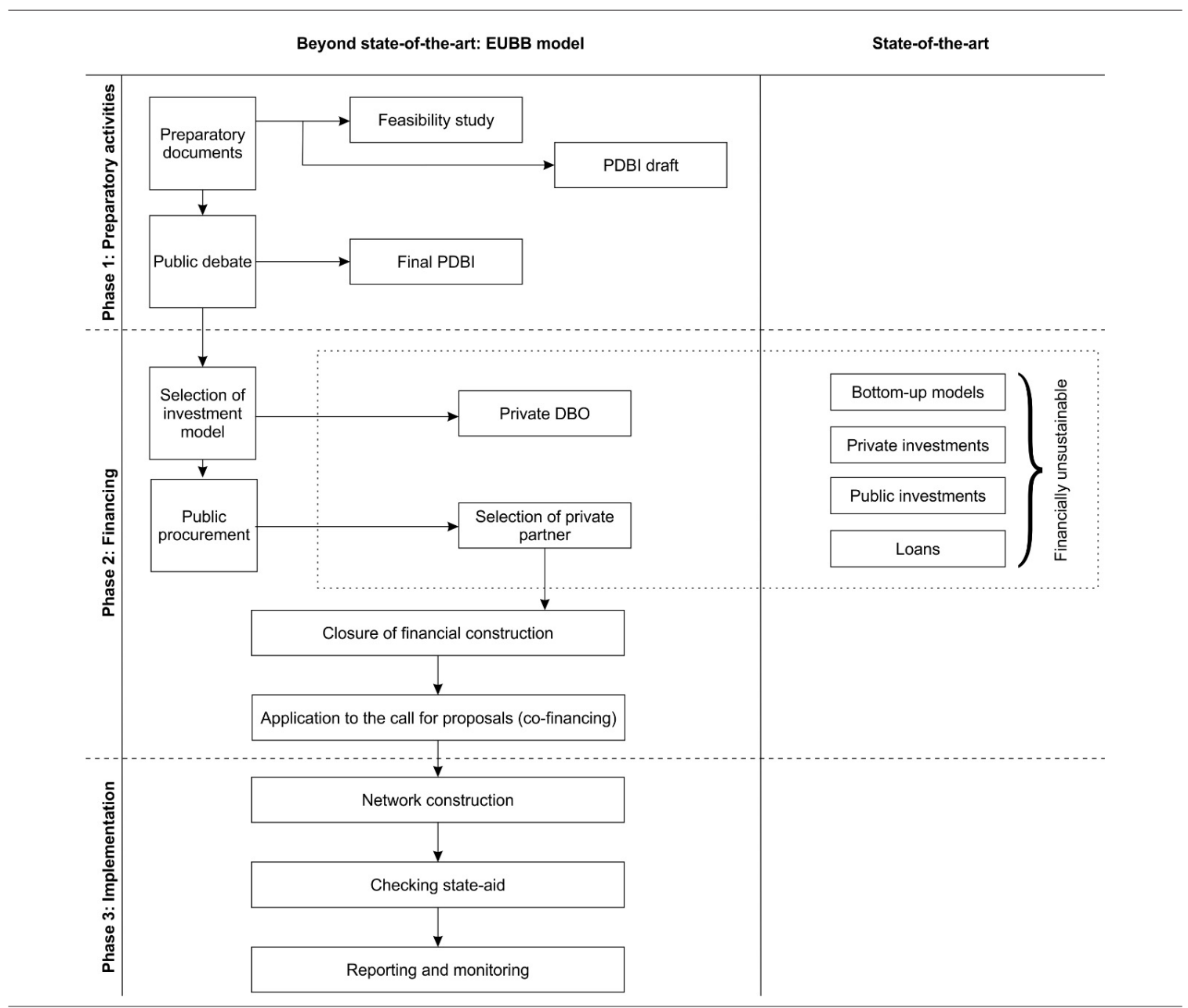

Figure 3. Project phases of broadband infrastructure construction 


\section{Phase 1: Preparatory activities}

The project starts with preparatory activities that include a feasibility study for the target area, and drafting of the development plan of broadband infrastructure (PBDI) in the target area. The PDBI draft initiates the process of public debate. The final version of PDBI includes all relevant comments of the interested public. In the project preparatory phase, it is crucial to accurately determine the number of private households, companies and public institutions for determining the newly built access ports. Considering the abovegiven, the governments must prepare a register and geolocation of those in advance, all in cooperation with the national geodetic administration, ministries of the interior, public authorities, as well as the chambers of crafts and commerce. As Maguire and Longley (2005) defined, geoportals connect geo-data providers and geo-data users via the Internet. According to the above-stated, geoportals are a powerful tool for the mapping process, which is essential to for preparing the geolocation of the broadband access coverage area (broadband atlas). The mapping process ${ }^{1}$ must be implemented by defining the following:

- Presenting the quality of Internet access,

- The quality level of approach and access conditions of the newly built network.

National geodetic administrations and other specified public data is merged with the telecommunication agencies data. Software processing provides the final results and exact locations with the specified access availability. In addition, the list of the existing infrastructure must be established to reduce project investment costs and accelerate project implementation.

\section{Phase 2: Financing}

Research conducted during the project implementation has shown that the construction of broadband infrastructure can be realized through

1 The mapping process is a process that determinates the quality (which is measured by speed) of the existing internet access on individual locations in a particular area. different investment models. The following three models are most frequently used:

- Private DBO (Design - Build - Operate),

- Public DBO,

- Public-private partnership (PPP).

Private DBO-private operator accepts the responsibility for designing the project, its construction and operations. Broadband network access remains in the ownership of the private operator. The private operator is herewith faced with an additional risk in terms of demand and the need to pre-finance the whole project (Palmer, 2000).

Public DBO-project leader or the local or regional governments (thus public authorities) take over the responsibility for designing, constructing and managing the network, while the newly constructed broadband access network remains in permanent public ownership. Public authorities also take over the project risks (Cave \& Martin, 2010).

PPP combines advantages of the previously mentioned investment models (Nucciarelli et al., 2010).

EUBB model defines criteria for selection of the investment model and the scheme for defining the impact of positive and negative criteria from the point of view of public authorities. Table 4 shows the framework of selection criteria of investment models, as defined through research.

Table 4 shows the optimal investment model (OIM) where:

(1) $y_{n}:[1,2,3]$

(2) $x_{m}:[1,2,3,4,5,6,7,8,9]$

is the particular one which results in variable $\mathrm{P}$ as the most frequent variable in the sequence ${ }^{x_{m}}$ :

(3) $f_{P}\left\{x_{m}\right\}$

Based on the demonstrated algorithm, we can conclude that:

(4) $O I M=y_{1}$

Appendix 2 shows a model for multi-criteria analysis. The model helps defining the most ap- 


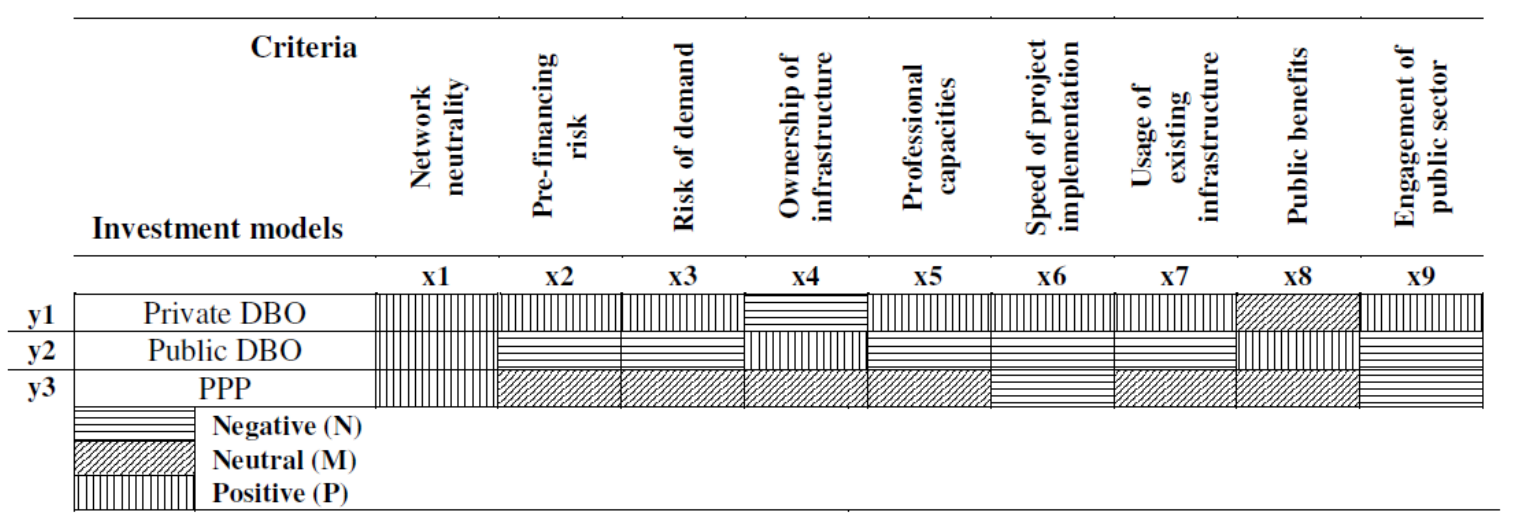

Table 4. Selection criteria of investment model for public administration bodies

propriate investment model for the specific area. The results of the multi criteria analysis are defined using the following algorithm:

(5) $T=I x V, X=\Sigma T$

where:

(6) $\Sigma I$ (criteria influence $)=1$

(7) $V$ (criteria importance $)=$ 1 to 5 , depending on the importance.

The model with the highest $\mathrm{X}$ is revealed as the optimal investment model for an area. Both criteria analysed throughout the research indicated that Private DBO is the optimal investment model for such projects. According to this model, the risk of project implementation is entirely coopted by the private operator, who also invests certain amount of his own financial funds into the project. As stated by Kalhagen and Elnegaard (2002), the key risk in broadband investments lays in low subscriber density, which is proportional to subscriber demand. Taking that into account, the private operator accepts the risk of demand and revenue generation in the EUBB model. The following steps shall include public procurement (selecting the private partner/operator), closing of the financial construction and submitting the project to the national call for proposals.

\section{Phase 3: Implementation}

Phase 3 begins with the network construction, as well as verification of state-aid before the new network becomes operational. Regarding the verification of state aid, in case that the reported investment costs are higher than initially anticipated, the highest acceptable amount of aid is limited to the value of the amount of state aid, specified in the public procurement process. Likewise, in case the reported amounts of state aid are lower than specified in public procurement, the eligible amount of support is limited to the precisely specified share of state aid in the reported investment costs. As explained by Papadias et al., (2009), the network operator has to ensure effective wholesale network access for a seven-year period of time. Proper monitoring and reporting has to be adequately fulfilled during the entire process.

\section{CONCLUSIONS}

Based on the research conducted, it can be concluded that despite relatively good preparation of documents that regulate the construction of broadband infrastructure in the areas without commercial interest of the operators, there are still certain challenges in BBAD project implementation. Therefore, public stakeholders need to assume a pragmatic approach, i.e. to collect and obtain essential data 
and information in an operable manner during the preparatory activities (feasibility study and PDBI). Private DBO model is considered the most eligible investment model in the optimal project areas of the Balkan countries. By selecting the private DBO model, the private operator as a private partner in the project accepts the total risk of pre-financing and the interest of end-users for network services (i.e. the risk of revenue demand and generation), while having sufficient technical capacity to implement the project within the optimal timeframe. Balkan countries or local and regional governments should therefore initiate these activities early, in order to carry out preparatory activities and to realize and implement their own PDBI. PDBI is the key document needed if the construction of broadband infrastructure is co-financed by the EU funds. If the PBDI as the key document for the project implementation is not adequately prepared, the preparatory process becomes more complex and challenging. If so, one cannot precisely define the project outputs needed for planning investment and operative costs, as well as estimated revenues of the newly constructed NGA network. Finally, it would be interesting to conduct further research on selecting stakeholders from public authorities that will control individual project phases.

\section{REFERENCES}

Briglauer, W., \& Gugler, K. (2013). The deployment and penetration of high-speed fiber networks and services: Why are EU member states lagging behind? Telecommunications Policy, 37(10), 819-835. doi:10.1016/j.telpol.2013.05.003.

Briglauer, W., \& Briglauer, W. (2014). The impact of regulation and competition on the adoption of fiber-based broadband services: Recent evidence from the European union member states. Journal of Regulatory Economics, 46(1), 51-79. doi:10.1007/ s11149-013-9237-4.

Briglauer, W., Cambini, C., \& Grajek, M. (2015). Why is Europe lagging on next generation access networks? Brussels: Bruegel. Retrieved December 12, 2015, from http://bruegel.org/wp-content/uploads/2015/10/pc_2015_14.pdf.
Cave, M., \& Martin, I. (2010). Motives and means for public investment in nationwide next generation networks. Telecommunications Policy, 34(9), 505512. doi:10.1016/j.telpol.2010.07.003.

Currie, M., Philip, L.J., \& Roberts, A. (2015). Attitudes towards the use and acceptance of eHealth technologies: a case study of older adults living with chronic pain and implications for rural healthcare. BMC health services research, 15(1), 1. doi:10.1186/ s12913-015-0825-0.

European Commission. (2010b). Europe 2020: A strategy for smart, sustainable and inclusive growth. COM (2010) 2020 final. Retrieved November 10, 2015, from http://eur-lex.europa.eu/legal-content/EN/ TXT/PDF/?uri=CELEX:52010DC2020\&from=EN.

European Commission. (2010a). A Digital Agenda for Europe. COM (2010) 245 final. Retrieved December 12, 2015, from http://eur-lex.europa.eu/legalcontent/EN/TXT/PDF/?uri=CELEX:52010DC024 $5 \mathrm{R}(01) \&$ from $=\mathrm{EN}$.

Grgurić, I. (2010). Europe 2020 - europska strategija za pametan, održiv i uključiv razvoj. Revija za socijalnu politiku, 8(1), 119-124. doi:10.3935/rsp.v18i1.963. In Croatian.

Gruber, H., Hätönen, J., \& Koutroumpis, P. (2014). Broadband access in the EU: An assessment of future economic benefits. Telecommunications Policy, 38(11), 1046-1058. doi:10.1016/j.telpol.2014.06.007.

Kalhagen, K.O., \& Elnegaard, N.K. (2002). Assessing broadband investment risk through option theory. Telektronikk, 98(2/3), 51-62. Retrieved November, 25, 2015, from http://www.telenor.com/wp-content/uploads/2012/05/T02_2-3.pdf\#page $=53$.

Katz, R.L. (2008). Ultrabroadband investment models. Communications and Strategies, 72, 99-116. Retrieved November 13, 2015, from https://www0. gsb.columbia.edu/mygsb/faculty/research/pubfiles/3275/UBB_kATZ.pdf.

Kongaut, C., \& Bohlin, E. (2014). Unbundling and infrastructure competition for broadband adoption: Implications for NGA regulation. Telecommunications Policy, 38(8), 760-770. doi:10.1016/j. telpol.2014.06.003.

Kramer, R.D.J., Lopez, A., \& Koonen, A.M.J. (2006). Municipal broadband access networks in the Netherlands-three successful cases, and how New Europe may benefit. In: 1st international conference on Access networks: ACM. doi:10.1145/1189355.1189367.

Lundvall, B.Å., \& Lorenz, E. (2012). From the Lisbon strategy to Europe 2020. In: N. Morel, B. Palier, J. Palme (Eds.), Towards a Social Investment Welfare State: Ideas, 
Policies and Challenges (pp. 333-352). Hamburg: Kovac. doi:10.1332/policypress/9781847429247.003.0013.

Maguire, D.J., \& Longley, P.A. (2005). The emergence of geoportals and their role in spatial data infrastructures. Computers, environment and urban systems, 29(1), 3-14. doi:10.1016/j.compenvurbsys.2004.05.012.

Marcus, J.S., \& Elixmann, D. (2012). Re-thinking the Digital Agenda for Europe (DAE): A richer choice of technologies. Studie für Liberty Global, September. Retrieved November 12, 2015, from http://www. wik-consult.de/uploads/media/Re-thinking_the_ Digital_Agenda_for_Europe.pdf.

Ministarstvo pomorstva, prometa i infrastrukture. (2014). Okvirni nacionalni program za razvoj infrastrukture širokopojasnog pristupa u područjima u kojima ne postoji dostatan komercijalni interes za ulaganja. Retrieved July 23, 2015, from http:// www.mppi.hr/UserDocsImages/MPPI_Okvirni_ program_NGA_BB\%2020-3_14\%20FINAL.pdf. In Croatian.

Ministarstvo regionalnog razvoja i fondova Europske unije. (2014). Operativni program "Konkurentnost $i$ kohezija". Retrieved November 14, 2015, from http:// www.mrrfeu.hr/UserDocsImages/01\%20OPKK\%20 2014-2020\%20hrv\%2027112014.docx. In Croatian.

Nucciarelli, A., Sadowski, B.M., \& Achard, P.O. (2010). Emerging models of public-private interplay for European broadband access: Evidence from the Netherlands and Italy. Telecommunications Policy, 34(9), 513-527. doi:10.1016/j.telpol.2010.07.004.

Osmanbegović, E., \& Rožajac, A. (2013). E-spremnost kao mjera razvijenosti informacionog društvapokazatelji e-spremnosti u zemljama zapadnog Balkana. Tranzicija, 15(31), 40-55. In Croatian.

Palmer, K. (2000). Contract issues and Financing in PPP/PFI (Do we need the 'F'in DBFO projects). UK: Institute For Public Policy Research (IPPR) Commission of Public Private Partnerships. Retrieved

\section{APPENDIX 1}

\section{Abbreviations}

DAE Digital Agenda for Europe

BBAD Broadband access development

DBO Design - Build - Operate

EU European Union

EUBB European Broadband

FTTC Fiber to the cabinet
September 4, 2015, from http://www.axrg05.dsl. pipex.com/docs/final_contract_issues.pdf.

Papadias, L., Chirico, F., \& Gaál, N. (2009). The new State aid broadband guidelines: not all black and white. Competition Policy Newsletter, 2009(3), 17-25. Retrieved November 28, 2015, from http:// broadband.cti.gr/el/download/broadband_guidelines.pdf.

Qiang, C.Z., Carlo M.R., \& Kaoru K. (2009). Economic impacts of broadband. Retrieved November 28, 2015, from http://siteresources.worldbank.org/ EXTIC4D/Resources/IC4D_Broadband_35_50.pdf.

Rampersad, G., \& Troshani, I. (2013). High-speed broadband: assessing its social impact. Industrial Management \& Data Systems, 113(4), 541-557. doi:10.1108/02635571311322784.

Roetter, M.F. (2013). Global broadband benchmarking 2013: best practice lessons for governments. Journal of Information Policy, 3, 619-666. doi:10.5325/ jinfopoli.3.2013.0619.

Tolušić, M, Koporčić, N., \& Tolušić, Z. (2013). Uloga i važnost EU fondova za Republiku Hrvatsku. Ekonomski Vjesnik, 26(1), 215-221. In Croatian.

Van der Wee, M., Verbrugge, S., Sadowski, B., Driesse, M., \& Pickavet, M. (2015). Identifying and quantifying the indirect benefits of broadband networks for e-government and e-business: A bottom-up approach. Telecommunications Policy, 39(3), 176-191. doi:10.1016/j.telpol.2013.12.006.

Veugelers, R. (2012). New ICT sectors: Platforms for European growth? Bruegel Policy Contribution, No. 2012/14. Retrieved December, 10, from https://www.econstor. eu/dspace/bitstream/10419/72131/1/722471483.pdf.

Zhen-Wei Qiang, C. (2010). Broadband infrastructure investment in stimulus packages: Relevance for developing countries. Info, 12(2), 41-56. doi:10.1108/14636691011027175.

FTTH Fiber to the house

GDP Gross Domestic Product

ICT Information and Communication Technologies

IT Information Technology

NGA Next Generation Access

OIM Optimal investment model

PDBI Development plan of broadband infrastructure

PPP Public Private Partnership 


\section{APPENDIX 2}

The model for multi criteria analysis

\begin{tabular}{|c|c|c|c|c|c|c|c|c|c|}
\hline \multirow{3}{*}{ Criteria } & \multicolumn{3}{|c|}{ Private DBO } & \multicolumn{3}{|c|}{ Public DBO } & \multicolumn{3}{|c|}{ PPP } \\
\hline & Ponder & Value & Total & Ponder & Value & Total & Ponder & Value & Total \\
\hline & I & $\mathrm{V}$ & $\mathrm{T}$ & I & $\mathrm{V}$ & $\mathrm{T}$ & $\mathrm{I}$ & $\mathrm{V}$ & $\mathrm{T}$ \\
\hline \multicolumn{10}{|l|}{ The value of investments } \\
\hline \multicolumn{10}{|l|}{$\begin{array}{l}\text { Operating costs and } \\
\text { revenues }\end{array}$} \\
\hline \multicolumn{10}{|l|}{ The necessary public funds } \\
\hline \multicolumn{10}{|l|}{$\begin{array}{l}\text { The optimal geographic } \\
\text { coverage }\end{array}$} \\
\hline \multicolumn{10}{|l|}{$\begin{array}{l}\text { The engagement of the } \\
\text { public sector }\end{array}$} \\
\hline \multicolumn{10}{|l|}{$\begin{array}{l}\text { The transfer of risk to the } \\
\text { private sector }\end{array}$} \\
\hline \multicolumn{10}{|l|}{$\begin{array}{l}\text { Ownership / control over } \\
\text { infrastructure }\end{array}$} \\
\hline \multicolumn{10}{|l|}{ Using existing infrastructure } \\
\hline \multicolumn{10}{|l|}{$\begin{array}{l}\text { Speed of network } \\
\text { construction }\end{array}$} \\
\hline \multicolumn{10}{|l|}{$\begin{array}{l}\text { The combination of different } \\
\text { technologies }\end{array}$} \\
\hline \multicolumn{10}{|l|}{ Introducing innovations } \\
\hline \multicolumn{10}{|l|}{$\begin{array}{l}\text { The amount of public } \\
\text { benefits }\end{array}$} \\
\hline TOTAL & & & $\mathrm{X}$ & & & $\mathrm{X}$ & & & $\mathrm{X}$ \\
\hline
\end{tabular}

\section{MODEL ZA USPEŠAN RAZVOJ INFRASTRUKTURE MREŽA}

\section{ZA PRISTUP SLEDEĆE GENERACIJE U ZEMLJAMA NA PODRUČJU BALKANA}

\section{Rezime:}

Nedostupnost brzog širokopojasnog pristupa internetu, prvenstveno usled izostanka komercijalnog interesa telekomunikacionih operatora, glavni je uzročnik ekonomske nerazvijenosti ruralnih područja na Balkanu. Razvoj širokopojasnog pristupa u ruralnim područjima predstavlja višestruk, složen i dugotrajan proces. U radu se ispituje trenutna dostupnost širokopojasnog pristupa u zemljama Balkana, analizira se algoritam sa konkretnim fazama razvoja širokopojasnog pristupa, kao i koristi koje donosi zainteresovanim stranama na nacionalnom i lokalnom nivou. Cilj ovog rada jeste da se razvije model koji racionalizuje razvoj širokopojasnog pristupa internetu. Autori nastoje da definišu način odabira investicionog modela za izgradnju širokopojasne infrastrukture. Dobijeni rezultati ukazuju na to da države Balkana moraju u što kraćem roku početi s pripremnim aktivnostima i analizama neophodnim za uspešnu primenu datog modela. Sprovedeno istraživanje u velikoj meri doprinosi smanjenju i zaustavljanju demografske i socio-ekonomske degradacije u manje razvijenim područjima i podsticanju njihovog razvoja.

\section{Ključne reči:}

koheziona politika, širokopojasna infrastruktura, model financiranja, EUBB model. 